\title{
A STUDY ON PYRAMID SCIENCES IN EGYPT
}

\author{
Y Sudheer Kumar Chowdary ${ }^{1}$ and K Ganesh ${ }^{2}$
}

\section{INTRODUCTION}

Most of the people who have a basic education have come across the Pyramids of Egypt at least once. Most of the people think of it as the "Tomb of a great Pharaoh" or a religious place. This is a huge misconception and is the biggest barrier between people and their attempt to get to understand the pyramids more deeply.

The first stepped pyramid in Egypt in Saqqara was completed in 2620 B.C. for the Third Dynasty Egyptian pharaoh Djoser. It had six levels and an underground burial chamber. Pyramid designers learned that if pyramids were going to be higher and have steeper slopes, their bases needed to be wider. At Dahshur, further upstream along the Nile from Saqqara, laborers started the construction of a pyramid for the Fourth Dynasty pharaoh Sneferu. Unfortunately, the designers chose a poor foundation, and the pyramid began to lean inward upon itself when it was about two-thirds complete. The builders reduced the angle of the upper portion to complete it and make it more stable, and it is now known as the Bent Pyramid (2565 B.C.). Unsatisfied with the Bent Pyramid, Sneferu ordered another pyramid at Dahshur. The designers chose a better foundation and made this pyramid the same height as the Bent Pyramid, but with a wider base and a shallower angle. The Red Pyramid was completed in 2560 B.C.The Great Pyramid of Khufu on the Giza plateau in Egypt is the largest and most elaborately constructed pyramid in existence, representing the most advanced aspects of pyramid construction.

Khufu's pyramid has the following features: The primary burial chamber, or king's chamber, contains the sarcophagus (tomb) that held Khufu's body, and the walls are adorned with hieroglyphs (writing) depicting various aspects of ancient Egyptian history and religion. The smaller queen's chamber (actually a misnomer -- it was not intended for the queen) lies within the pyramid, while another unfinished secondary burial chamber lies underneath the pyramid.

Weight-relieving chambers above the king's chamber distribute the weight of the overlying rock and prevent the king's chamber from collapsing. The gallery is a large passageway with a vaulted, corbelled ceiling (the walls are layered upward, and each vertical layer sticks out further than the one below to form a primitive arch). Descending and ascending passageways connect various chambers to each other and to the outside. Air shafts connect the king's chamber to the outside. They may have been designed as a way for Khufu's spirit to exit the pyramid and rise to the heavens. The entrance was sealed after the pharaoh's body was placed inside. White limestone rocks line the pyramid's exterior, giving it a smooth face. These rocks have eroded away over time, but we know they existed because the Pyramid of Khafre still has some on its peak. However, after the very earliest period of Egyptian history, the tombs of kings

\footnotetext{
${ }^{1}$ Department of Civil engineering BMS College of engineering, Bangalore, Karnataka, India

${ }^{2}$ Department of Civil Engineering BMS College of engineering, Bangalore, Karnataka, India
} 
were almost always complexes, having other buildings and structures other than the tomb itself. Almost all royal tombs, including pyramids, had a mortuary temple where priests were supposed to take care of the king's soul (known as his Ka). During the Pyramid Age, the mortuary temple was located right next to the pyramid itself, though after the Pyramid Age, the mortuary temple was separated from the tomb so that the tomb's location would be less obvious to grave robbers. Other structures usually included a valley temple, usually near the Nile River, which was sort of an entrance to the complex, a causeway, which was a corridor that led from the valley temple to the mortuary temple, and usually a "cult pyramid", which was a smaller pyramid set next to the larger one. We think that the cult pyramid was probably built for the king's Ka. Usually, the pyramid complex was surrounded by a wall, known as an enclosure wall. Pyramid complexes also typically contained other tombs or smaller pyramids belonging to the king's wives and other family members, and there were also pits dug for boats, which were the boats that carried the dead king in his funeral, or were symbolic boats for his journey through the afterlife. Other parts of the greater pyramid complex might include storage buildings, a village for the workers who built the pyramid, and housing for the priests who took care of the dead king. All of these pyramids are near Cairo, but there are a few others that are further south. One building which was probably the pyramid of Khui, though it is very ruined, is located in Dara, which is about in the middle of the Nile Valley, called Middle Egypt. The last pyramid built by Ahmose I is even further south, at Abydos. The only other pyramids built for burial purposes that we know of in Egypt were the non-royal pyramids of the workers who lived at Deir el-Medina on the West Bank at Luxor (ancient Thebes). There are, however, a series of small step pyramids that were not tombs that stretch from Seila in the north to Elephantine Island in the south. We are really not very sure of the purpose of these small pyramids. However, we should also note that the Nubians, who lived further south in what is now the Sudan, also built pyramids used for tombs, though their royal pyramids were more similar to the nonroyal ones at Deir el-Medina.

Pyramids in Egypt were only one type of tomb used mostly to bury kings and sometimes queens during a specific period of time. The "Pyramid Age" lasted from about the 3rd Dynasty reign of Djoser (2630 BC) until the Reign of Ahmose Me, which ended in about 1514 BC. However, few of the kings after the 12th Dynasty (ending in about 1759 BC) seem to have built pyramids. Before the Pyramid Age, kings were buried in tombs known as mastabas, because from a distance they look like Arabic benches, and that is the term in Arabic for a bench. After the Pyramid Age, kings were buried in rock cut tombs that they tried to hide from tomb robbers. There was no structure above ground at the tomb to give its location away.

\section{MATERIALS USED}

The pyramids were built of limestone, granite, basalt, gypsum (mortar), and baked mud bricks. Limestone blocks were quarried at Giza and possibly other sites. Granite likely came from upriver at Aswan. Alabaster came from Luxor and basalt from the Fayoum depression. Many of the pyramids were built with a number of different stone materials. Most of the material used was fairly rough, low grade limestone used to build the pyramid core, while fine white limestone was often employed for the outer casing as well as to cover interior walls. Egypt is a country rich in stone and was sometimes even referred to as the "state of stone". In particular, Egypt has a great quantity of limestone formation, which the Egyptians called "white stone", because during the Cretaceous period Egypt was covered with seawater. The country is also rich in sandstone, but it was never really used much until the New Kingdom. Limestone seems to have first been employed in the area of Saqqara, where it is of poor quality but layered in regular, strong formations as much as half a meter thick. This limestone is coarse grained with yellow to greenish gray shading. The layers are separated from each other by thin layers of clay and the coloration may vary according to layer. It could often be quarried very near the building sites, and quarries have been found at Saqqara, Giza, Dahshur and other locations. In order to quarry this stone, the blocks were marked out with just enough space in between each to allow for a small 
passageway for the workers to cut the blocks. The workmen would use a number of different tools to cut the blocks, including copper pickaxes and chisels, granite hammers, dolerite and other hard stone tools. The finer, white limestone employed in the pyramids and mortuary temples was not as easy to quarry, and had to be found further from the building site. One of the man sources for this limestone was the Muqattam hills on the west bank of the Nile near modern Tura and Maasara. This stone lay buried further from the surface, so tunnels had to be dug in order to reach the actual stone quarry. Sometimes these deposits were as deep as fifty meters, and huge caverns had to be built to reach the quarry. Generally, large chunks of stone were removed, and then finely cut into blocks. The blocks were then moved to the building site on large wooden sledges pulled by oxen. The path they took would be prepared with a mud layer from the Nile in order to facilitate the moving. Iron tools were not available, so workers used copper and stone-cutting tools to carve out the blocks in the quarries. They then used levers to move the stone blocks away from the quarry site.

\section{CONSTRUCTION OF A PYRAMID}

- Surveying and excavation: Egyptian builders probably made plans and models of the pyramid. The projects were overseen by the pharaoh's master builder, or vizier.

The collapse of the Medium pyramid and the shift of the Bent Pyramid taught builders that foundations were important. Once engineers found a suitable site with a good foundation, they had to lay out the site. Pyramid sides always ran parallel to the north-south and east-west axes. The builders didn't have compasses, and there was no North Star at the time (the Earth's rotation wobbles like a top and the position of true north in the sky changes over a 40,000-year cycle). So, they used the movements of circumpolar stars or the sun to figure out true north. Using sighting rods and circles, they could trace arcs of the rising and setting stars or the sun's shadow, measure the angles to the ends of the arc, and calculate true north. Once they established that, they could find the other directions with lines and right angles. The ancient Egyptians used "cubits" (the length from the tip of your middle finger to your elbow) and "hands" (the width of your hand with the thumb on the side) for measurements. They dug post holes at regular intervals ( 10 cubits) along the base outline and laid out the site in a grid. Then, laborers excavated and leveled the foundation. No one is sure of the exact method, but they were extremely exact -- the base of Khufu's pyramid is level to 2 centimeters (less than an inch).There are two main theories about leveling methods: Workers poured water into the excavated site and leveled all material above the waterline. Then they lowered the water level and removed more material, continuing the process until the foundation was level.

- Transporting building materials: Again, no one knows how laborers were able to get the 2.5-ton stone blocks from the quarries to the building site. Wheels wouldn't have been useful on the desert sand and gravel, so they most likely dragged the blocks with wooden sleds and ropes. Some think that workers used quarter-circle wooden sleds that fit around a rectangular block. They attached the sleds to the block, and a crew of about eight men rolled them along the ground, much like rolling a keg of beer. Others say the laborers used wooden rollers. For long-distance transport, the blocks were loaded on barges and transported down the Nile. Workers dug canals to get the barges nearer to the site.

Egyptologists estimate that workers placed $\neg$ about 300 stones a day during pyramid construction. Several theories -- lever systems, ramps and kites, for example: attempt to explain how the huge blocks got into place. Those in the know generally accept the ramp idea, but they debate the exact ramp configurations. The ramps could have been long and straight, perpendicular to the sides or wrapped around the core. While laborers placed stones in the core, stone cutters were making the chambers, passageways and shafts in the pyramid's interior. Artists inscribed the designs that adorned the chamber walls.

\section{PYRAMID WORK FORCE}


The Greek historian Herodotus described the building of Khufu's pyramid by more than 100,000 slaves. But when Harvard archaeologist Mark Lehner led an expedition to uncover clues about the people who built the pyramids, he found no evidence of housing for such a large population. Instead, his group discovered housing and food storage places for small gangs of workers. The significance of a Pyramid: The ancient Egyptians believed that there is an afterlife after the death of a Pharaoh. So, after a pharaoh dies, his dead body was mummified and was enclosed in a case which was kept within the pyramid. That is why a pyramid is mistaken as a tomb. The truth is, this pyramid behaved as a carrier of the pharaoh's body and soul from his life to afterlife. The pyramid had all the necessary items needed by a person to live a glorious life after death. The truth came to the archaeologists after they dug up the base and found the sarcophagus of a buffalo in the Khafre's pyramid. Hence, it was concluded that pyramids are just symbolisms of a chariot taking a pharaoh from this world to that world. Khufu's pyramid even contains shafts for the pharaoh to breathe, so is believed. It appears that at any one time about 2,000 workers were on site, divided into two large divisions and smaller groups of about 200 men.

Historical Theories: The ancient Egyptians believed that there is an afterlife after the death of a Pharaoh. So, after a pharaoh dies, his dead body was mummified and was enclosed in a case which was kept within the pyramid. That is why a pyramid is mistaken as a tomb. The truth is, this pyramid behaved as a carrier of the pharaoh's body and soul from his life to afterlife. The pyramid had all the necessary items needed by a person to live a glorious life after death. The truth came to the archaeologists after they dug up the base and found the sarcophagus of a buffalo in the Khafre's pyramid. Hence, it was concluded that pyramids are just symbolisms of a chariot taking a pharaoh from this world to that world. Khufu's pyramid even contains shafts for the pharaoh to breathe, believed. Pyramid energy: In a magnetic field like the inside of a pyramid, the produced magnetism is in a direction opposite to that of iron where the field-direction is outward from the North pole and inward to the South pole of a magnet. In other words in a pyramid the direction of its magnetic field is outward from the south pole of the pyramid and inwards to the north pole. The pyramid shape generates a spin field from its apex for electrons, meaning that they can move in an angular momentum, i.e. around their own axis. So, if moving or kinetic energy enters the pyramid at the top opening, this can be taken as the north pole of its magnetic field and as the pyramid emits energy from its middle, this can then be taken as the south pole of its magnetic field. Once it entered into the pyramid, the energy bounces from the equal sides of its walls while the five angles of the pyramid project a beam of radiation towards the center where the energy is collected or pooled to form the "fire in the middle" (the word pyramid is translated as 'fire in the middle').

These energies all combine in the center or King's chamber area of, i.e. the Great Pyramid. The molecules or atoms in this area absorb these energies by resonance. The corners are then, in effect, a type of nano-wave radiator. As the energy increases, the electron orbits start to expand; as more energy is absorbed, more expansion occurs and as the energy increases, there is an increase in circulation and finally we have a highly saturated energy atmosphere in the wave bands around $10 \mathrm{~nm}$. These energies also radiate outwards from the corners of the pyramid. Pyramid energy is a life-giving force called biocosmic energy, which allows for the pyramid to become a kind of cosmic antenna that tunes into vast energy sources, receives the energy and changes itself into a magnetic field. While most of the positive energy is focused within and beneath the pyramid, some is also diffused from the five points or angles.

Many people who have stood on top of the Great Pyramid have described sensing a high energy field or electrical charge. Depending on the material it is built with, i.e. some kind of crystal or stone such as granite or marble, a pyramid will create a spherical field of harmonic vibrations around itself. Rose granite, which was used in the construction of the King's Chamber of the Great Pyramid, is one of the most paramagnetic substances that has the ability to alter the magnetic field in the area it occupies. Limestone, which covered the Great Pyramid on the outside, is a diamagnetic substance in that it is 
repelled by both poles of a magnet - being repelled then, the energy moves right through its walls to the outside. According to Joe Parr, a member of the Great Pyramid of Giza Research Association, any pyramidal shape will theoretically attract and trap certain mass particles and it is these particles that produce the orb-like energy field, also called a containment bubble, around any true pyramid that shields out other energies. It does so in order to cleanse the atmosphere outside around the structure enabling all other elements and vibrations to move towards the harmony and therefore making what is negative, positive. In this process, destructive energies are deflected and positive energies are enhanced.

streaming into the earth: Pyramid energy weakens radiation consisting of waves of energy associated with electric and magnetic fields resulting from the acceleration of an electric charge, i.e. gamma rays. One of the aspects of the power of pyramids is that the atmospheric energy in and around a pyramid is contained in a spherical aetheric energy field centered at the 1/3 height level of the pyramid. This energy field is called a third dimensional energy bubble that has been tested and measured by scientists and it was found that every now and then Pyramids quit responding to recordings and measurements.

This means that the force field around the pyramid becomes totally non-conductive to all known forces that are generally negative. - Parr has also found that the width of the energy containment bubble or orb expands and contracts with the phases of the moon. This suggests again that the spherical orb on the outside of the pyramid is a static torsion field that gathers around the pyramid and is strengthened by absorbing other dynamic torsion fields. These fields can be strengthened by the electrostatic energy in the ions or in the acoustic vibration of air, which also is a vibration of the ether. The best passive torsion generators are formed by cones or pyramidal shapes built according to the "phi" ratio of 1 to 0.618 and it can, therefore, be said the pyramid shape has the power to harness torsional energy because torsion waves are phi-spirals and for this reason a pyramid will hold positive energy and deflects negative energy wavelengths and therefore inhibit natural decay: "Pyramids don't kill bacteria. However the bacteria feed by absorbing nutrients as entropy breaks the tissues down. In a pyramid there is so little entropy that the bacteria barely survive and don't multiply prolifically. Food therefore stays fresher longer and has a chance to dehydrate before it goes bad."

\section{RESULTS}

The following are the results obtained:

- The growth of the seeds stored in the pyramid shows $30-100 \%$ yield in 1-5 days. The pyramid grown sprouts lasted over a week without spoilage.

- Water inside the pyramid will remain liquid to minus 40 degrees Celsius but freeze instantly if jostled or bumped in any way.

- Immune power of human beings improved by meditating in the pyramid as shown in plates 1 and 2.

There have been a lot of research under the great scientist Nikola Tesla and the pyramids had inspired him to build his own Power Generation Station that was based on the same principles as the Pyramids of Egypt. Striking feature of this station is, the distance of the station from the equator and the distance of the pyramids of Giza from the equator are in Harmonic progression. It is interesting to note that results seem to show that increasing the height of the pyramid improves the quality of the results. 


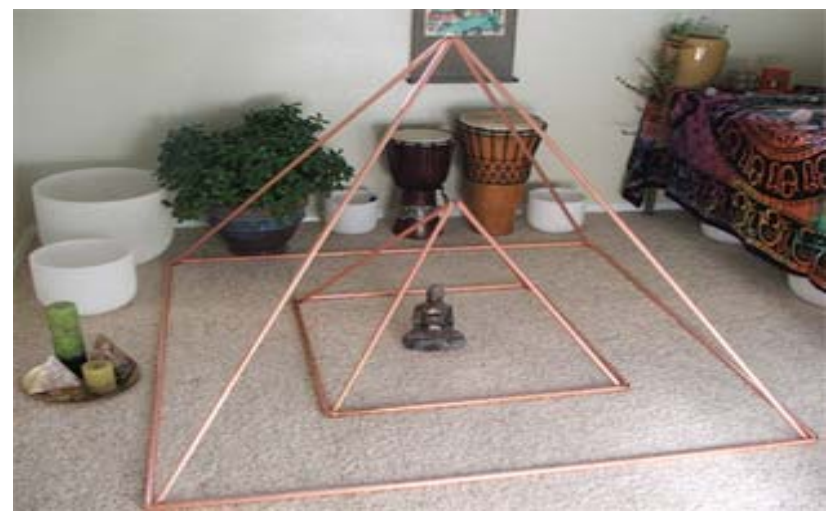

\section{PLATE 1: PYRAMID ENERGY}

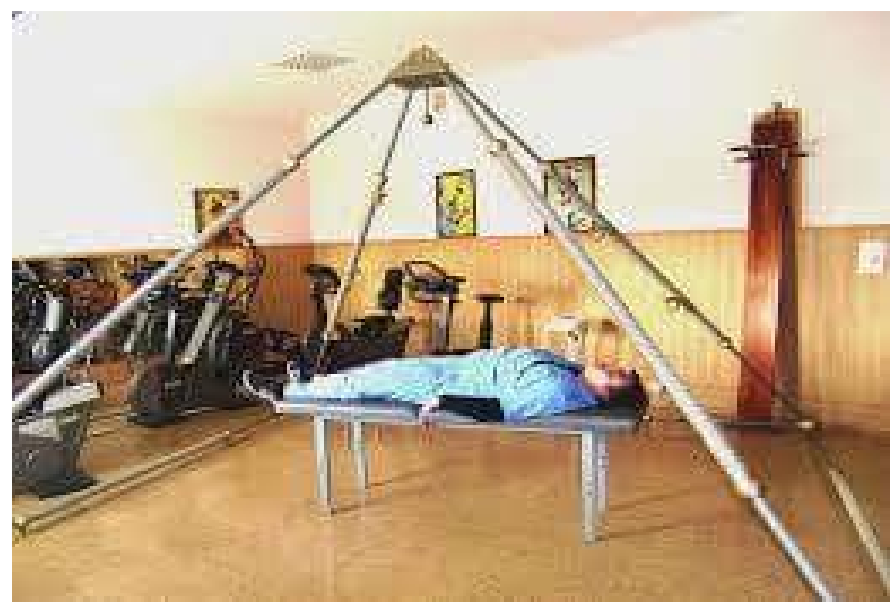

PLATE 2: MEDITATION INSIDE THE PYRAMID

\section{VI.CONCLUSIONS}

- A lot of questions are yet to be answered, and some of the answers might be something that we are not developed enough to accept as of now.

- We can use the power of pyramids to our most. Its generation power, healing powers and other string theories regarding the pyramids of giza are really valuable information. This research would bring us closer to our ancestors and unravel a lot of mysteries.

- As shown in the above figures pyramid energy is quite a lot compare to outside atmosphere.

\section{REFERENCES}

1. The message of the sphinx, graham Hancock and Robert Bauval, Egypt, 1996.

2. Pyramidology, 4 volumes, Adam Rutherford, Egypt, 1957-1972.

3. The great pyramid decoded, E. Raymond apt, Egypt, 1993

4. The Orion mystery, Robert Bauval and gilbert Adrian, Egypt, 1994

5. The Great Pyramid -its divine message, David Davidson, Egypt, 1928

6. The Great Pyramid Decoded, Peter Lemesurier, Egypt, 1977

7. The Great Pyramid, your personal guide, peter Lemesurier, Egypt, 1987

8. Cosmic Debris: METEORITES in history, John G. Burke, Egypt, 1986 
9. The book of the dead, Sir Wallis budges, Egypt, 1994

10. The Riddle of the pyramids, Kurt Mendelssohn, Egypt, 1975

11. The world's last mysteries, reader's digest, Egypt, 1978

12. Serpent in the sky, the high wisdom on ancient Egypt, John Anthony west, 1993

13. The Great Pyramid: man's monument to man, Valentine, Egypt, 1975

14. Pyramid power, Max toth and Greg Nielsen, Egypt, 1976

15. The great pyramid: Signs in the sun, John E. Gangstad, Egypt, 1976

16. Giza The Truth, Ian Lawton and Chris Ogilvie-Herald, Egypt, 1999

17. The giza power plant, Christopher dunn, Egypt, 1998 